\title{
Perbedaan Prestasi Belajar Matematika Ditinjau dari Self-Efficacy dan Mathematic Anxiety Siswa SMP di Depok
}

\author{
Mia Anggraeni ${ }^{1}$, Riana Sahrani ${ }^{2}$, Rahmah Hastuti ${ }^{3}$ \\ ${ }^{1}$ Fakultas Psikologi, Universitas Tarumanagara, Jakarta \\ Email: mia25sept@gmail.com \\ ${ }^{2}$ Fakultas Psikologi, Universitas Tarumanagara, Jakarta \\ Email:rianas@fpsi.untar.ac.id \\ ${ }^{3}$ Fakultas Psikologi, Universitas Tarumanagara, Jakarta \\ Email:rahmahh@fpsi.untar.ac.id
}

\begin{abstract}
ABSTRAK
Untuk menguasai dan menciptakan teknologi di masa depan diperlukan penguasaan matematika yang kuat. Penelitian yang dilakukan oleh TIMSS dan PISA menunjukkan bahwa prestasi belajar matematika siswa Indonesia usia 15 tahun tergolong masih rendah jika dibandingkan dengan prestasi belajar matematika siswa lain di dunia. Beberapa faktor yang memengaruhi prestasi belajar matematika ini diantaranya adalah self-efficacy dan mathematic anxiety. Tujuan penelitian ini adalah untuk menguji perbedaan prestasi belajar matematika ditinjau dari self-efficacy dan mathematic anxiety. Penelitian ini menggunakan desain kuantitatif non-experimental dengan menggunakan teknik dan analisis Mann-Whitney. Partisipan penelitian ini adalah siswa SMP dari tiga sekolah yang ada di Depok sebanyak 385 orang. Teknik pengambilan sampel dengan purpossive sampling. Pengambilan data dilaksanakan pada bulan Oktober 2016. Instrumen penelitian berupa kuesioner self-efficacy dan mathematic anxiety dengan skala Likert serta data sekunder prestasi belajar matematika siswa berupa nilai rapor terakhir. Hasil penelitian pengujian hipotesis dilakukan dengan analisis Mann-Whitney. Hasil penelitian menunjukkan ( $Z=-$ $2,791$ dan $p=0.005<0,05)$ bahwa ada perbedaan prestasi belajar matematikaditinjau dari self-efficacy (selfefficacy rendah dan tinggi). Hasil penelitian juga menunjukkan $(Z=-2,695$ dan p sebesar $0.007<0,05)$ bahwa ada perbedaan prestasi belajar matematikaditinjau dari mathematic anxiety (mathematic anxiety rendah dan tinggi). Hasil penelitian ini dapat memprediksikan prestasi belajar matematikasiswaberdasarkan self-efficacy dan mathematic anxiety yang dimiliki oleh siswa tersebut.
\end{abstract}

Kata kunci: self-efficacy, mathematic anxiety, prestasi belajar matematika, matematika

\section{PENDAHULUAN}

Matematika merupakan salah satu bidang ilmu pengetahuan yang memegang peranan penting dalam perkembangan ilmu pengetahuan dan teknologi (Yahaya, Ramli, Hashim, Ibrahim \& Zakariya, 2009). Untuk menguasai dan menciptakan teknologi di masa depan diperlukan penguasaan matematika yang kuat. Namun, kenyataan yang terjadi penguasaan matematika siswa di Indonesia terbilang rendah. Penguasaan siswa terhadap matematika dikenal dengan prestasi belajar matematika. Prestasi belajar matematikaadalah kemampuan, penguasaan dan pemahaman siswa terhadap matematika (Anjum, 2006).

Hasil studi oleh Trends in International Mathematics and Science Study (dikutip dalam Mullis, Martin, Foy \& Arora, 2012) pada tahun 2011 diketahui bahwa prestasi matematika siswa Indonesia berada pada urutan ke-38 dari 42 negara dengan skor rata-rata 386. Sedangkan survei yang dilakukan oleh OECD pada tahun 2014 menggunakan tes Programme for International Student Assesment (PISA) menyatakan bahwa prestasi matematika Indonesia berada pada peringkat 64 dari 65 negara yang mengikuti PISA.

Bandura (1997) mengatakan bahwa self-efficacy merupakan keyakinan akan kemampuan individu untuk dapat mengorganisasi dan melaksanakan serangkaian tindakan yang dianggap perlu untuk mencapai suatu hasil yang diinginkan. 
Pada umumnya seorang siswa dengan self-efficacy yang tinggi akan lebih mudah dan berhasil melampaui latihan-latihan matematika yang diberikan kepadanya dibandingkan siswa yang memiliki self-efficacy rendah. Self-efficacy berpengaruh positif terhadap prestasi belajar siswa. (Pajares \& Miller, 1994; Ayotola \& Adedeji, 2009; Liu \& Koirala, 2009; Kitsantas, Cheema, Ware, 2011; Sartawi, Alsawaie, Dodeen, Tibi \& Alghazo, 2012; Li, 2012; Goulau, 2014).

Mathematic anxiety merupakan perasaan ketegangan dan kecemasan yang membuat kesalahan pada angka dan penyelesaian masalah matematika dalam lingkup luas dalam kehidupan seharihari dan situasi sekolah (Richardson \& Suinn dikutip dalam Sherman \& Wither, 2003).

Pengamatan yang dilakukan terhadap SMP X yang ada di daerah Depok menunjukkan enam dari dua puluh siswa menunjukkan sikap selalu bertanya pada guru setiap kali mengerjakan tugas matematika. Mereka juga sering terlihat ragu-ragu dalam menyelesaikan tugasnya serta mudah menyerah terutama dalam mengerjakan soal-soal yang sulit.Ciri-ciri tersebut menunjukkan bahwa keyakinan siswa terhadap kemampuannya dalam menyelesaikan tugas-tugas matematika rendah. Istilah keyakinan terhadap kemampuannya di bidang matematika dalam kajian psikologi disebut dengan istilah mathematic self-efficacy. Berdasarkan kajian dari Bandura (1997), ciri-ciri siswa yang memiliki self-efficacy yang rendah yaitu tidak yakin dapat menghadapi masalahnya, menghindari masalah yang sulit, mengurangi usaha dan cepat menyerah ketika menghadapi masalah, ragu pada kemampuan diri yang dimilikinya, aspirasi dan komitmen pada tugas rendah. Meskipun keadaan enam siswa tersebut demikian, berdasarkan informasi yang diberikan oleh guru kelas dan bagian administrasi sekolah menunjukkan bahwa nilai yang diperoleh siswasiswa tersebut sudah dapat mencapai nilai Kriteria Ketuntasan Minimal (KKM) atau nilai standar minimal pelajaran tersebut (Komunikasi Personal, 2 Agustus 2016).

Personal communication yang dilakukan terhadap tiga siswa lain di SMPS X mengatakan bahwa mereka tegang saat belajar matematika. Mereka tidak dapat duduk tenang, melihat jam dinding berulang kali saat pelajaran matematika dan bingung menjawab saat guru memberikan pertanyaan. Ciri-ciri tersebut menunjukkan bahwa siswa mengalami perasaan tegang saat belajar matematika. Perasaan tegang dalam menghadapi persoalan sering disebut kecemasan. Istilah kecemasan di bidang matematika dalam kajian psikologi dikenal dengan istilah mathematic anxiety. Meskipun demikian, informasi dari guru kelas mengatakan bahwa nilai matematika dari siswa-siswa tersebut dapat mencapai nilai Kriteria Ketuntasan Minimal (KKM) atau nilai standar minimal pelajaran tersebut. Sementara ada dua siswa lain yang menunjukkan sikap sebaliknya, yaitu duduk tenang saat belajar matematika serta percaya diri hampir di setiap mengerjakan tugas matematika memiliki nilai matematika yang sama tingginya (Komunikasi Personal, 3 Agustus 2016).

Hasil penelitian terdahulu mengatakan bahwa siswa dengan self-efficacy dan mathematic anxiety berbeda akan memiliki prestasi belajar matematika yang berbeda. Namun fakta di lapangan menunjukkan tidak ada perbedaan prestasi belajar matematika pada siswa yang memiliki selfefficacy dan mathematic anxiety yang berbeda.Perbedaan antara hasil penelitiandengan fakta di lapangan serta masih sedikitnya penelitian di Indonesia mengenai perbedaan prestasi belajar matematika ditinjau dari self-efficacy dan mathematic anxiety merupakan landasan untuk membuat suatu penelitian untuk menyelidiki perbedaan prestasi belajar matematika ditinjau dari self-efficacy dan mathematic anxiety.

Rumusan masalah dalam penelitian ini adalah meneliti : (1) apakah terdapat perbedaanprestasi belajar matematika ditinjau dari self-efficacy siswa SMP di Depokdan (2) apakah terdapat 
perbedaan prestasi belajar matematikaditinjau dari mathematic anxiety siswa SMP di Depok? Penelitian ini bertujuan untuk (1) mengetahui perbedaan prestasi belajar matematika ditinjau dari self-efficacy siswa SMP di Depok dan (2) untuk mengetahui perbedaan prestasi belajar matematikaditinjau dari mathematic anxiety siswa SMP di Depok.

\section{METODE PENELITIAN}

Partisipan penelitian ini adalah siswa SMP yang ada di Depok dengan rentang usia 13-16 tahun. Partisipan penelitian ini tidak dibatasi dengan jenis kelamin, etnis, agama dan status sosial.

Data demografis profil partisipan penelitian mengenai jenis kelamin, tempat dan tanggal lahir, hobi, tinggal bersama, kelas, asal SD, pelajaran yang disukai dan yang tidak disukai, keikutsertaan les matematika dan tidak ikut les matematika dan orang yang menemani belajar di rumah.

Instrument penelitian berupa kuesioner self-efficacy dan mathematic anxiety dengan skala Likert serta data sekunder prestasi belajar matematika siswa berupa nilai rapor terakhir.

Kuesioner yang digunakan untuk mengukur variabel self-efficacy disusun berdasarkan kajian teori dari Bandura (1997) yang terdiri dari dua puluh tujuh item. Ada 14 butir pernyataan positif dan ada 13 butir pernyataan negatif. Skor dimulai dari satu sampai empat. Skor satu menunjukkan sangat tidak setuju (STS) dan empat menunjukkan sangat setuju (SS) untuk butir positif. Sedangkan untuk butir negatif, skor satu menunjukkan sangat setuju (SS) dan skor 4 menunjukkan sangat tidak setuju (STS). Contoh Butir Kuesioner Self-Efficacy dapat dilihat pada tabel 1 .

Tabel 1. Contoh butir kuesioner self-efficacy

\begin{tabular}{|c|c|c|c|c|c|}
\hline No & Pernyataan & STS & TS & $\mathbf{S}$ & SS \\
\hline 1 & $\begin{array}{l}\text { Saya yakin dapat berusaha untuk mengerjakan } \\
\text { tugas matematika walaupun sepertinya terlalu } \\
\text { sulit. }\end{array}$ & & & & \\
\hline 2 & $\begin{array}{l}\text { Saya yakin mencapai hasil maksimal dalam } \\
\text { mengerjakan sesuatu yang belum pernah saya } \\
\text { kerjakan sebelumnya. }\end{array}$ & & & & \\
\hline
\end{tabular}

Kuesioner yang digunakan untuk mengukur variabel mathematic anxiety, akan diadaptasi dari Mathematic Anxiety Rating Scale-Revised yang dikembangkan oleh Plake dan Parker (dikutip dalam Ozcan \& Brewer, 2011) yang terdiri dari 24 pernyataan. Skala penilaian yang digunakan dalam kuesioner mathematic anxiety adalah skala Likert. Skor dimulai dari satu sampai lima.

Tabel 2. Contoh butir kuesioner mathematic anxiety

\begin{tabular}{|c|c|c|c|c|c|c|}
\hline No & Pernyataan & $\begin{array}{r}\text { Tidak } \\
\text { pernah }\end{array}$ & Jarang & Kadang & Sering & Selalu \\
\hline 1 & $\begin{array}{l}\text { Saya takut ketika bersiap-siap belajar } \\
\text { matematika }\end{array}$ & & & & & \\
\hline 2 & $\begin{array}{l}\text { Saya tidak takut ketika belajar dan les } \\
\text { matematika }\end{array}$ & & & & & \\
\hline
\end{tabular}

Butir nomor satu sampai dengan butir nomor delapan serta butir nomor 17 sampai 20 adalah pernyataan positif dengan skor jawaban menggunakan skala Likert $(5=$ selalu sampai dengan $1=$ tidak pernah). Butir nomor 9 sampai 16 serta butir nomor 21 sampai 24 adalah pernyataan negatif dengan skor jawaban menggunakan skala Likert $\quad(1=$ selalu sampai dengan $5=$ tidak pernah).Contoh butir kuesioner mathematic anxiety ditampilkan pada tabel 2 . 
Hasil uji validitas dan reliabilitas alat ukur self-efficacy masing-masing dimensi disajikan dalam tabel 3, 4 dan 5.

Tabel 3. Gambaran butir dimensi level

\begin{tabular}{|c|c|c|c|c|}
\hline Dimensi & & Butir Positif & Butir Negatif & Alpha Cronbach \\
\hline \multirow[t]{2}{*}{ Level } & Sebelum & 5 & 5 & 0,734 \\
\hline & Sesudah & 5 & 4 & 0,739 \\
\hline
\end{tabular}

Tabel 4. Gambaran butir dimensi generality

\begin{tabular}{ccccc}
\hline Dimensi & & 3Butir Positif & Butir Negatif & Alpha Cronbach \\
\hline Generality & Sebelum & 5 & 4 & 0,367 \\
& Sesudah & 3 & 2 & 0,756 \\
\hline
\end{tabular}

Tabel 5. Gambaran butir dimensi strength

\begin{tabular}{ccccc}
\hline Dimensi & Butir Positif & Butir Negatif & Alpha Cronbach \\
\hline \multirow{2}{*}{ Strength } & Sebelum & 4 & 4 & 0,597 \\
& Sesudah & 3 & 4 & 0,595 \\
\hline
\end{tabular}

Hasil uji validitas dan reliabilitas alat ukur mathematic anxiety masing-masing dimensi disajikan dalam tabel 6 dan 7.

Tabel 6. Gambaran butir dimensi learning mathematic anxiety

\begin{tabular}{clccc}
\hline Dimensi & Butir Positif & Butir Negatif & $\begin{array}{c}\text { Alpha } \\
\text { Cronbach }\end{array}$ \\
\hline Learning Mathematic Anxiety & Sebelum & 8 & 8 & 0,801 \\
& Sesudah & 4 & 8 & 0,860 \\
\hline
\end{tabular}

Tabel 7. Gambaran butir dimensi mathematic evaluation anxiety

\begin{tabular}{clccc}
\hline Dimensi & & Butir & Butir & Alpha \\
& & Positif & Negatif & Cronbach \\
\hline Mathematic Evaluation Anxiety & Sebelum & 4 & 4 & 0,784 \\
& Sesudah & 3 & 4 & 0,803 \\
\hline
\end{tabular}

Prosedur penelitian dibedakan dalam dua tahap yaitu tahap persiapan dan tahap pelaksanaan penelitian. Tahap persiapan meliputi penentuan masalah, melakukan kajian kepustakaan, menyusun alat ukur, melakukan proses adaptasi alat ukur (melalui proses BTM, content validity dan vace validity), dan melakukan uji validitas dan reliabilitas alat ukur. Tahap pelaksanakan penelitian meliuti pengambilan data dengan menyebar kuesioner dan melakukan analisis dan pembahasan berdasarkan data yang didapatkan dengan pengolahan data secara statistik menggunakan teknik analisis Mann-Whitney.

Hipotesis dalam penelitian ini adalah : a) ada perbedaan prestasi belajar matematikaditinjau dari self-efficacy b) ada perbedaan prestasi belajar matematika ditinjau dari mathematic anxiety. 


\section{HASIL DAN PEMBAHASAN}

Untuk mengetahui perbedaan prestasi belajar matematika ditinjau dari self-efficacy dan mathematic anxiety digunakan analisis Mann-Whitney.

Berdasarkan hasil analisis data uji Mann-Whitney diketahui bahwa ada perbedaan prestasi belajar matematikaditinjau dari self-efficacy yang rendah dan tinggi. Hal ini ditunjukkan dengan nilai $\mathrm{Z}$ $=-2,791$ dan $\mathrm{p}=0.005<0,05$ yang artinya hipotesis diterima, maka terdapat perbedaan prestasi belajar matematika ditinjau dari self-efficacy.

Berdasarkan hasil analisis data uji Mann-Whitney diketahui bahwa ada perbedaan prestasi belajar matematika ditinjau dari mathematic anxiety yang rendah dan tinggi. Hal ini ditunjukkan dengan nilai $\mathrm{Z}=-2,695$ dan $\mathrm{p}$ sebesar $0.007<0,05$ yang artinya hipotesis diterima, maka terdapat perbedaan prestasi belajar matematika ditinjau dari mathematic anxiety.

Berdasarkan hasil uji korelasi dengan menggunakan korelasi Spearman antara variabel selfefficacy dengan variabel prestasi belajar matematikadiperoleh nilai $r=0,181$ dan $p=0,000<$ 0,01 jadi terdapat hubungan positif yang menandakan semakin tinggi self-efficacy maka semakin tinggiprestasi belajarmatematikapartisipan.

Pengolahan data dilanjutkan dengan uji korelasi antara variabel mathematic anxiety dengan variabel prestasi belajar matematika. Hasil yang diperoleh adalah nilai $r=-0,173$ dan $p=0,001$ $<0,01$ jadi terdapat hubungan negatif yang menandakan semakin tinggi mathematic anxiety maka semakin rendah prestasi belajar matematikapartisipan. Hal ini berlaku sebaliknya, semakin rendah athematic anxiety maka semakin tinggi prestasi belajar matematikapartisipan.

Setelah dilakukan uji beda dengan teknik uji Mann-Whitney untuk self-efficacy, kesukaan terhadap matematikamerupakan faktor yang memengaruhi self-efficacy setiap orang berbeda. Hal ini ditunjukkan oleh nilai $\mathrm{Z}=-2,818 \mathrm{p}=0,005<0,05$. Sedangkan hasil uji beda yang lain menunjukkan bahwa tidak ada perbedaan self-efficacy berdasarkan jenis kelamin, usia, tingkat pendidikan dan keikutsertaan dalam les matematika.

Hasil uji beda untuk mathematic anxiety menunjukkan bahwa faktor kesukaan terhadap matematika, pendidikan ayah dan pendidikan ibu merupakan faktor yang memengaruhi mathematic anxiety setiap orang berbeda.

Setelah dilakukan uji beda dengan teknik uji Mann-Whitney untuk mathematic anxiety diperoleh nilai $\mathrm{Z}=-4,723, \mathrm{p}=0,000<0,05$. Dengan demikian, ada perbedaan yang signifikan antara mathematic anxiety dengan kesukaan terhadap matematika. Mathematic anxiety lebih tinggi pada partisipan yang tidak suka terhadap matematika dan mathematic anxiety lebih rendah pada partisipan yang suka matematika.

Teknik uji Kruskal Wallis untuk mathematic anxiety diperoleh nilai Chi-Square $=13,767$ dan $\mathrm{p}=$ $0,008<0,05$. Dengan demikian, ada perbedaan mathematic anxiety ditinjau dari pendidikan terakhir ayah. uji beda dengan teknik uji Kruskal Wallis untuk mathematic anxiety diperoleh nilai Chi-Square $=15,757$ dan $\mathrm{p}=0,003<0,05$. Dengan demikian, ada perbedaan mathematic anxiety ditinjau dari pendidikan terakhir ibu. 
Hasil uji beda untuk prestasi belajar matematika menunjukkan bahwa faktor kesukaan terhadap matematika, pendidikan ayah, pendidikan ibu, pekerjaan ibu dan kondisi orang tua yang hidup atau meninggal merupakan faktor yang memengaruhi mathematic anxiety setiap orang berbeda. Hasil uji Mann-Whitney terhadap prestasi belajar matematika ditinjau dari kesukaan terhadap matematika menunjukkan nilai $Z=-3,748$ dan $p=0,000<0,05$. Hal ini menunjukkan bahwa ada perbedaan yang signifikan antara prestasi belajar matematika dengan kesukaan terhadap matematika.

Hasil uji Kruskal Wallis terhadap prestasi belajar matematikaditinjau dari pendidikan ayah diperoleh nilai Chi-Square $=15,803$ dan $\mathrm{p}=0,003<0,05$. Dengan demikian, ada perbedaan prestasi belajar matematika ditinjau dari pendidikan ayah.

Hasil uji Kruskal Wallis terhadap prestasi belajar matematikaditinjau dari pendidikan ibu diperoleh nilai Chi-Square $=19,460$ dan $p=0,001<0,05$. Hal ini menunjukkan bahwa ada perbedaan prestasi belajar matematika ditinjau dari pendidikan ibu.

Setelah dilakukan uji beda dengan teknik uji Kruskal Wallis untuk prestasi belajar matematikaditinjau dari pekerjaan ibudiperoleh nilai Chi-Square $=17,894$ dan $\mathrm{p}=0,003<0,05$. Dengan demikian, ada perbedaan prestasi belajar matematikaditinjau dari pekerjaan ibu.

Setelah dilakukan uji beda dengan teknik uji Mann-Whitney untuk prestasi belajar matematika ditinjau dari kondisi orang tuadiperoleh nilai $Z=-2,194$ dan $p=0,028<0,05$. Dengan demikian, ada perbedaan yang signifikan antara prestasi belajar matematika ditinjau dari kondisi orang tua hidup atau meninggal.

Prestasi belajar matematika siswa SMP di Depok berbeda ditinjau dari self-efficacy dan mathematic anxiety siswa tersebut. Hasil temuan empiris dari penelitian ini sesuai dengan penelitian yang mengatakan bahwa self-efficacy memiliki pengaruh besar dalam prestasi belajar matematika. Siswa dengan self-efficacy tinggi memiliki prestasi belajar matematika tinggi. Sebaliknya jika siswa memiliki self-efficacy rendah maka prestasi belajar matematika siswa tersebut juga rendah (Pajares \& Graham, 1999; Zimmerman, 2000; Pajares \& Schunk, 2001).

Hasil penemuan ini juga sesuai dengan penelitian Erdogan, Kesici dan Sahin (2011) yang menyatakanbahwa mathematic anxietymenjadi penyebab signifikan yang dapat menghalangiprestasi belajar matematikasiswa. Semakin tinggi mathematic anxiety maka semakin rendah prestasi belajar matematikasiswa tersebut.

Uji korelasi menunjukkan bahwa terdapat hubungan positif antara self-efficacy dengan prestasi belajar matematika. Hal ini sejalan dengan penelitian terdahulu yang mengatakan bahwa selfefficacy berpengaruh positif terhadap prestasi belajar siswa (Ayotola \& Adedeji, 2009; Pajares \& Miller, 1994; Liu \& Koirala, 2009; Nasiriyan, Azar, Noruzy, \& Dalvand, 2011; Kitsantas, Cheema, Ware, 2011; Sartawi, Alsawaie, Dodeen, Tibi \& Alghazo, 2012; Li, 2012; Goulau, 2014). Semakin tinggi self-efficacy maka semakin tinggi pula prestasi belajar matematika.

Penelitian terdahulu mengatakan bahwa siswa dengan tingkat kecemasan yang tinggi akan memperoleh pencapaian matematika yang rendah (Pourmoslemi, Erfani, \& Firoozfar, 2013). Dalam penelitian ini juga menunjukkan hubungan yang negatif antara mathematic anxiety dengan prestasi belajar matematika. 
Latar belakang keluarga dan status ekonomi memengaruhi prestasi belajar matematika(Chiu\&Xi Hua, 2008). Hasil penelitian terdahulu ini sesuai dengan penelitian ini dalam hal pendidikan orang tua, pekerjaan ibu dan kondisi orang tua yang hidup atau meninggal. Penelitian ini menghasilkan temuan empiris bahwa ada perbedaan yang signifikan dari prestasi belajar matematikaditinjau dari pendidikan ayah dan ibu. Orang tua dengan pendidikan tinggi cenderung akan memberikan perhatian dan pengarahan yang baik untuk anaknya. Perhatian dan pengarahan orang tua yang baik membuat anak akan siap dalam mengikuti pelajaran di sekolah (Sakdiyah, 2011). Orang tua yang memiliki tingkat pendidikan yang lebih tinggi memiliki sumber daya yang cenderung lebih besar, baik pendapatan, waktu, tenaga, dan jaringan kontak, yang memungkinkan mereka untuk terlibat lebih jauh dalam pendidikan anak (Slameto, 2003). Selain itu, hasil penelitian juga menunjukkan bahwa ada perbedaan yang signifikan dari prestasi belajar matematika berdasarkan pekerjaan ibu. Hal ini sangat mungkin terjadi karena sebagian besar yang berperan dalam menemani siswa belajar ketika di rumah adalah ibunya.

Salah satu faktor yang memengaruhi prestasi belajar matematika adalah penggunaan televisi dan games (Kölleretal. dikutip dalam Kupari, 2006; Singh et al., 2002). Namun hasil penelitian ini menunjukkan tidak ada perbedaan yang signifikan dari prestasi belajar matematika pada siswa yang suka melakukan aktivitas menonton televisi dan games dengan siswa yang tidak suka melakukan aktivitas menonton televisi dan games. Hal ini dapat terjadi karena tidak semua kegiatan menonton televisi berdampak buruk. Terdapat juga dampak baik tergantung kepada kepatutan (tepat-usia) acara yang ditonton, waktu menonton sehingga tidak menyita waktu yang sebenarnya digunakan untuk belajar dan membuat PR misalnya, yang berkaitan dengan program sekolah (Wulandari, 2014).

Hasil penelitian terhadap prestasi belajar matematika menunjukkan bahwa ada perbedaan prestasi belajar matematikaantara yang suka dengan yang tidak suka dengan matematika. Hal ini sejalan dengan penelitian terdahulu yang mengatakan bahwa siswa dengan mathematics attitude yang tinggi akan memiliki prestasi belajar matematikayang tinggi (Else-Quest, Hyde, \& Linn, 2010; Singhetal., 2002; Winheller et al., 2013). Hal ini karena enjoyment of mathematics merupakan salah satu dimensi dari mathematics attitude.

Berkaitan dengan penelitian mengenai self-efficacy, hasil penelitian menunjukkan bahwa terdapat perbedaan self-efficacy antara yang suka dan yang tidak suka dengan matematika. Namun, hasil penelitian menunjukkan bahwa tidak ada perbedaan self-efficacy berdasarkan jenis kelamin. Hal ini berbeda dengan penelitian yang dilakukan oleh Bandura (1997) yang mengatakan bahwa jenis kelamin merupakan salah satu faktor yang memengaruhi self-efficacy. Hasil penelitian juga menunjukkan bahwa tidak ada perbedaan yang signifikan dari self-efficacy berdasarkan kelas dan usia. Hal ini berbeda dengan yang disampaikan Bandura (1997) yang mengatakan bahwa tingkat pendidikan dan usia memengaruhi tingkat self-efficacy. Tidak adanya perbedaan self-efficacy berdasarkan tingkat pendidikan dalam penelitian ini sangat mungkin terjadi karena meskipun partisipan tersebut berasal dari kelas satu sampai kelas tiga, namun tidak ada perbedaan jenjang pendidikan karena semua partisipan adalah siswa SMP. Hasil penelitian juga menunjukkan bahwa tidak ada perbedaan yang signifikan dari self-efficacy berdasarkan keikutsertaan dalam les matematika.

Peker (2009) menyebutkan bahwa faktor intelektual memengaruhi mathematic anxiety. Nilai rapor merupakan salah satu indikator untuk mengukur tingkat intelektual. Analisis data utama menunjukkan bahwa ada perbedan prestasi belajar matematika berupa nilai rapor ditinjau dari mathematic anxiety. Hal ini menunjukkan kesesuaian antara hasil penelitian dengan penelitian 
terdahulu. Berkaitan dengan penelitian tentang mathematic anxiety, hasil penelitian menunjukkan bahwa ada perbedaan yang signifikan dari mathematic anxiety berdasarkan kesukaan terhadap matematika, Pendidikan terakhir ayah dan pendidikan terakhir ibu. Peker (2009) menyebutkan bahwa faktor psikologis memengaruhi mathematic anxiety. Minat merupakan salah satu aspek psikologis. Minat yang diteliti dalam penelitian ini berupa suka atau tidak siswa terhadap matematika. Hal ini menunjukkan bahwa hasil penelitian ini sesuai dengan penelitian yang dilakukan sebelumnya mengenai faktor psikologis memengaruhi mathematic anxiety.

Peker (2009) juga mengatakan bahwa faktor lingkungan dan sosial memengaruhi mathematic anxiety. Hasil dari penelitian ini yang berkaitan dengan lingkungan menunjukkan bahwa ada perbedaan yang signifikan dari mathematic anxiety berdasarkan pendidikan terakhir ibu.

Berdasarkan uji beda yang dilakukan terhadap jenis kelamin dan keikutsertaan dalam les matematika menunjukkan bahwa tidak ada perbedaan yang signifikan dari mathematic anxiety berdasarkan jenis kelamin dan keikutsertaan dalam les matematika.

\section{KESIMPULAN}

Berdasarkan analisis data yang telah dilakukan mengenai perbedaan prestasi belajar matematika ditinjau dari self-efficacy dan mathematic anxiety siswa SMP di Depok diperoleh hasil bahwa ada perbedaan prestasi belajar matematika ditinjau dari self-efficacy. Hal ini ditunjukkan dengan nilai $\mathrm{Z}=-2,791$ dan $\mathrm{p}=0.005<0,05$ yang artinya hipotesis diterima. Hasil penelitian juga menunjukkan bahwa ada perbedaan prestasi belajar matematika ditinjau dari mathematic anxiety siswa SMP di Depok. Hal ini ditunjukkan dengan nilai $Z=-2,695$ dan p sebesar $0.007<0,05$ yang artinya hipotesis diterima.

\section{Ucapan Terima Kasih (Acknowledgement)}

Ucapan terima kasih penulis sampaikan kepada pihak- pihak yang mendukung penelitian ini :

1.Ibu Dr. Rostiana, Psikolog selaku Dekan Fakultas Psikologi Universitas Tarumanagara, Jakarta,

2.Bapak Dr. P. Tommy S. Suyasa, M.Si., Psi. selaku Ketua Program Studi Magister Psikologi, Fakultas Psikologi, Universitas Tarumanagara, Jakarta,

3.Ibu Dr. Riana Sahrani, M.Si., Psi. selaku dosen pembimbing utama

4.Ibu Rahmah Hastuti, M.Si., Psi. selaku dosen pembimbing ke dua

5.Seluruh Dosen Psikologi Universitas Tarumanagara yang telah membimbing dan memberikan ilmu kepada penulis selama masa perkuliahan.

6.Bapak Sofyan A Djalil, Ph.D dan ibu Ratna Megawangi, Ph.D sebagai Dewan Pembina Indonesia Heritage Foundation (IHF), serta ibu Drg. Rahma Dewi, M.Kes sebagai Direktur Indonesia Heritage Foundation (IHF).

7.Bapak dan ibu Kepala Sekolah SMP yang ada di Depok

8.Siswa-siswa SMP di Depok yang berpartisipasi dalam penelitian ini.

\section{REFERENSI}

Anjum, R. (2006). The impact of self-efficacy on mathematics achievement of primary school children. Pakistan Journal of Psychological Research, 21(3-4), 61-78.

Ayotola, A. \& Adedeji, T. (2009). Therelationship between mathematics self efficacy and achievement in mathematics. Procedia Social and Behavioral Sciences.

Bandura, A. (1997). Self-efficacy in changing societies. New York: Cambridge University Press. 
Goulau, M.D.F. (2014). The relationship between self-efficacy and academic achievement in adults' learners. Athens Journal of Education, 1(3), 237-246.

Kitsantas, A., Cheema, J., \& Ware,H. W. (2011). Mathematics achievement: The role of homework and self-efficacy beliefs. Journal of Advanced Academics, 22(2), 310-339.

Li, L.K.Y. (2012). A study of the attitude, self-efficacy, effort and academic achievement of cityu students towards research methods and statistics. SS-Student E-Journal, 1, 154-183.

Liu, X. \& Koirala, H. (2009). The effect of mathematics self-efficacy on mathematics achievement of high school students. Northeastern Educational Research Association.

Mullis, I.V.S., Martin, M.O., Foy, P., \& Arora, A. (2011). TIMSS 2011: International results in mathematics. Lynch School of Education: TIMSS \& PIRLS International Study Center.

OECD. (2014). PISA 2012 results in focus: what 15-years old know and what they can do with what they know. Canada: OECD.

Ozcan, A.Y. \& Brewer, S. (2011). Adaptation of mathematics anxiety rating scale-revised (marsr) for adult online students. $27^{\text {th }}$ Annual Conference on Distance Teaching and Learning.

Pajares, F., \& Miller, M.D. (1994). Role of self-efficacy and self-concept beliefs in mathematical problem solving: a path analysis. Journal of Educational Psychology, 86(2), 193-203.

Sartawi, A. A., Alsawaie, O. N., Dodeen, H., Tibi, S., \& Alghazo, I. M. (2012). Prediction mathematics achievement by motivation and self efficacy across gender and achievement levels. Interdisiplinary Journal of Teaching and Learning, 2(2), 59-77.

Sherman, B. F. \& Wither, D. P. (2003). Mathematics anxiety and mathematics achievement. Mathematics Education Research Journal, 15(2), 138-150.

Yahaya, A., Ramli, J., Hashim, S., Ibrahim, A., Zakaria, Z. (2009). The relationship between school, class and co-curriculum absenteeism on the academic performance of selected secondary school. Journal of Social Sciences, 5, 355-361. 